\title{
The Use of Negative-pressure Wound Therapy with Instillation Before and After Grafting in the Surgical Management of Hidradenitis Suppurativa
}

\section{Hidradenitis Suppurativanın Cerrahi Tedavisinde Greftleme Öncesi ve Greftleme Sonrası Yıkamalı Negatif Basınçlı Yara Kapama Kullanımı}

\author{
(1) Emin Sır¹, ๑ Alper Aksoy², ๑) Ahmet Deniz Uçar³ \\ ${ }_{1}^{1}$ Private Practice, Clinic of Plastic, Reconstructive and Aesthetic Surgery, Izmir, Turkey \\ 2Konur Hospital, Clinic of Plastic, Reconstructive and Aesthetic Surgery, İzmir, Turkey \\ 3University of Health Sciences, İzmir Bozyaka Training and Research Hospital, Clinic of General Surgery, İzmir, Turkey
}

\section{HIIIIII| ABSTRACT}

Aim: Hidradenitis suppurativa (HS) is a chronic infection of apocrine sweat glands. HS related morbidities such as chronic infection, and carcinoma development reduce the life quality of the patients. Non-surgical management cannot provide complete recovery. The aim of the surgical treatment of HS is full control of the illness and prevention of recurrence.

Method: From January 2014 to May 2018, ten male patients underwent treatment of HS in the gluteal and sacral area. A protocol of wide excision, followed by negative pressure wound therapy with instillation (NPWTi) to decrease bioburden and promote angiogenesis of defect area and a splitthickness skin graft was used. The mean age was 40 years. Patients are examined for granulation tissue formation, graft condition, hospitalization time, and recurrence.

Results: The period for granulation tissue formation was 5.4 (4-8) days. NPWTi was put off on the fifth day after surgical excision and graft were observed three more days with wound dressing. Patients were discharged on the $10^{\text {th }}$ postoperative day. The mean hospitalization time was 14.3 (range $=12-16$ ) days. There was no graft loss in nine patients. Approximately $20 \%$ of graft loss was observed in one patient. Secondary healing was obtained with local wound care measures in this patient. The patients had neither contour irregularity nor contracture. There was no recurrence after a median of 23.4 (range=12-36) months follow-up time.

Conclusion: NPWTi can be used in the surgical management of HS either at graft preparation period or after grafting for better graft survival rate and shorter hospitalization duration.

Keywords: Hidradenitis suppurativa, negative pressure wound therapy with instillation, skin grafting

\section{||||||||||| ÖZ}

Amaç: Hidradenitis suppurativa (HS) apokrin ter bezlerininin kronik enfeksiyonudur ve hastanın yaşam kalitesini düşürerek birçok morbitideye sebep olur. Cerrahi olmayan tedaviler günümüzde tam olarak kür sağlamamaktadır. Cerrahi tedavi amacı hastalığı kontrol altına almak ve nüksü önlemektir.

Yöntem: Çalışmaya Ocak 2014-Mayıs 2018 arasında gluteal veya sakral bölgesindeki HS nedeniyle ameliyat edilen 10 hasta dahil edildi. Anjiyonegenezi hızlandırmak ve bakteri yükünü azaltmak amacıyla geniş eksizyonu takiben yıkamalı negatif basınçlı yara kapama uygulandı. Granülasyon formasyonunun ardından bütün defektler kısmi kalınlıkta deri grefti ile onarıldı. Hastaların ortalama yaşı 40 idi ve bütün hastalar granülasyon formasyonunun oluşma süresi, greft durumu, hastanede yatış süresi ve rekürrens açısından değerlendirildi.

Bulgular: Granülasyon dokusunun en kısa 4, en uzun 8. günde geliştiği görüldü (ortalama 5,4 gün). Cerrahi eksizyon sonrası 5. gün negatif basınçlı yara kapması çıarılan hastalarda greft 3 gün daha pansuman ile takip edildi. Greft operasyonundan 10 gün sonra hastalar taburcu edildi. Ortalama yatış süresi 14,3 gündü (en kısa 12, en uzun 16). Hastalara uygulanan kısmı kalınlıkta deri greftinin 9 tanesinde problem izlenmezken 1 hastanın

Address for Correspondence/Yazışma Adresi: Alper Aksoy MD,

Konur Hospital, Clinic of Plastic, Reconstructive and Aesthetic Surgery, İzmir, Turkey

Phone: +90 5334671480 E-mail: aksoya@gmail.com ORCID ID: orcid.org/0000-0002-8993-4103

Received/Geliş Tarihi: 12.06.2019 Accepted/Kabul Tarihi: 05.07.2019

${ }^{\circ}$ Copyright 2019 by Turkish Society of Colon and Rectal Surgery

Turkish Journal of Colorectal Disease published by Galenos Publishing House. 
greftinde yaklaşık \%20 kayıp gözlendi. Bu hasta lokal yara bakımı ile takip edildi ve sekonder iyileşme sağlandı. Hastaların uzun dönem takiplerinde rekürrens, deri greftine bağlı kontür bozukluğu ve kontraktür gözlenmedi.

Sonuç: HS cerrahisi sonrası yıkamalı negatif basıcçlı yara kapama kullanımı gerek grefte hazırlık aşamasında, gerekse greft uygulandıktan sonra greft yaşam şansını artırmak için kullanılabildiği gibi hastaların hastanede yatış süresini kısaltmaktadır.

Anahtar Kelimeler: Hidradenitis suppurativa, damlatma ile negatif basınçlı yara tedavisi, deri grefti

\section{Introduction}

Hidradenitis (HS) is a chronic and relapsing inflammatory disease of the skin and subcutaneous tissue. The term HS comes from the Latin words hidros (sweat) and aden (gland). The obstruction of the hair follicles and sebaceous glands leads to this condition. Secondary infections due to the occlusion of apocrine sweat glands with keratin plug and stasis in the glandular component are responsible for the development of HS. ${ }^{1}$ Rupture of the follicles after an acute infection causes the spreading of the infection through the subcutaneous fat tissue. HS is predominantly seen in the areas where apocrine sweat glands are abundant such as the axilla, breast, perianal, and gluteal regions. Prevalence is $1 / 300-600$, and it is infrequent before puberty and after 40 years. Diabetes mellitus, cigarette smoking, immunosuppressive conditions, and poor hygiene are some predisposing factors. Familial forms of HS with autosomal dominant form were reported in some studies. It is more common in females than their male counterparts. ${ }^{2,3,4}$ Hurley, in his study, divided HS into three groups based on sinus tract formation, tract connection, abscess volume, and presence of cicatrization (Table 1). ${ }^{5}$ Different treatment modalities were defined concerning this classification. Proper hygiene measures, immunotherapy, local or systemic antimicrobials, and androgen treatment can be applied in Hurley stage 1, whereas Hurley stage 2 disease requires simple drainage, marsupialization, excision, and primary closure and various laser therapies can be done. Unfortunately, all the treatment modalities described above for both Hurley 1 and 2 stages are not enough for the prevention of disease spread. In the case of stage 3 disease, in which widespread disease is a case, wide excisions and reconstructive surgical interventions are mandatory. Repairment with skin grafts, negative pressure wound therapy (NPWT) with skin grafting, local flaps, and

Table 1. Hurley's staging system for Hidradenitis suppurativa

$\begin{array}{ll}\text { Stage } & \text { Characteristics } \\ 1 & \begin{array}{l}\text { Solitary or multiple isolated abscess formation without } \\ \text { scarring or sinus tracts }\end{array} \\ 2 & \begin{array}{l}\text { Recurrent abscesses, single or multiple widely separated } \\ \text { lesions, with sinus tract formation }\end{array} \\ 3 & \begin{array}{l}\text { Diffuse or broad involvement across a regional area with } \\ \text { multiple interconnected sinus tracts and abscesses }\end{array}\end{array}$

closure with perforator flaps can be listed for HS surgical treatment at Hurley stage 3 disease. ${ }^{6,7,8,9}$ However, there is no gold standard for reconstructive treatment preferences. NPWT is a commonly used management method for chronic wounds, pressure ulcers, intractable venous ulcers, skin graft applications, and anterior chest wall wounds secondary to mediastinitis. ${ }^{10,11,12,13}$ With the use of this method, easy wound dressing can be achieved at the sites where skin grafting is hard to apply. Besides this, reduced contamination, fastened granulation tissue formation, protection of the wound edges from sharing forces are beneficial effects of NPWT with instillation (NPWTi), which leads to reduced hospital stay time. ${ }^{14}$ This study aimed to reduce wound dressing in terms of number, pain and hospitalization time, increase in graft survival, and send back the patients to their social life as early as possible by using continuous irrigation NPWTi in gluteal and perianal HS cases.

\section{Materials and Methods}

Between January 2011 and December 2014, ten male patients with long-lasting gluteal and/or perianal HS were recruited in this study (Table 2 ). All patients were operated for diverting loop colostomy under spinal anesthesia in the supine position. Patients were repositioned at prone position afterward, and infected, bad-smelling tissues were excised with a two $\mathrm{cm}$ healthy margin until the deep subcutaneous fat level. After hemostasis NPWTi (VAC Ulta, Texas, KCI) was applied without prior wound size reduction procedure in the operating room. Standard saline solution was used for irrigation in all patients. Granulation tissue formation was examined by wound opening on the $2^{\text {nd }}$ postoperative day. Patients thought to have enough granulation tissue formation were re-operated under spinal anesthesia. Split thickness skin graft obtained from the posterior thigh was laid down on to the wound bed and stabilized with a skin stapler. The skin graft was covered with gauze, and NPWTi were applied on it. Wound dressing was kept closed during the continuing four days. Graft condition was checked on the $5^{\text {th }}$ postoperative day. After the fifth postoperative day, wound dressing was carried out with antimicrobial containing topical pomade for three more days. Patients were discharged after this $3^{\text {rd }}$ day, and outpatient follow-up was carried out for graft loss, recurrence, contour deformity, and pain (Figure 1). 
Table 2. Patient characteristics

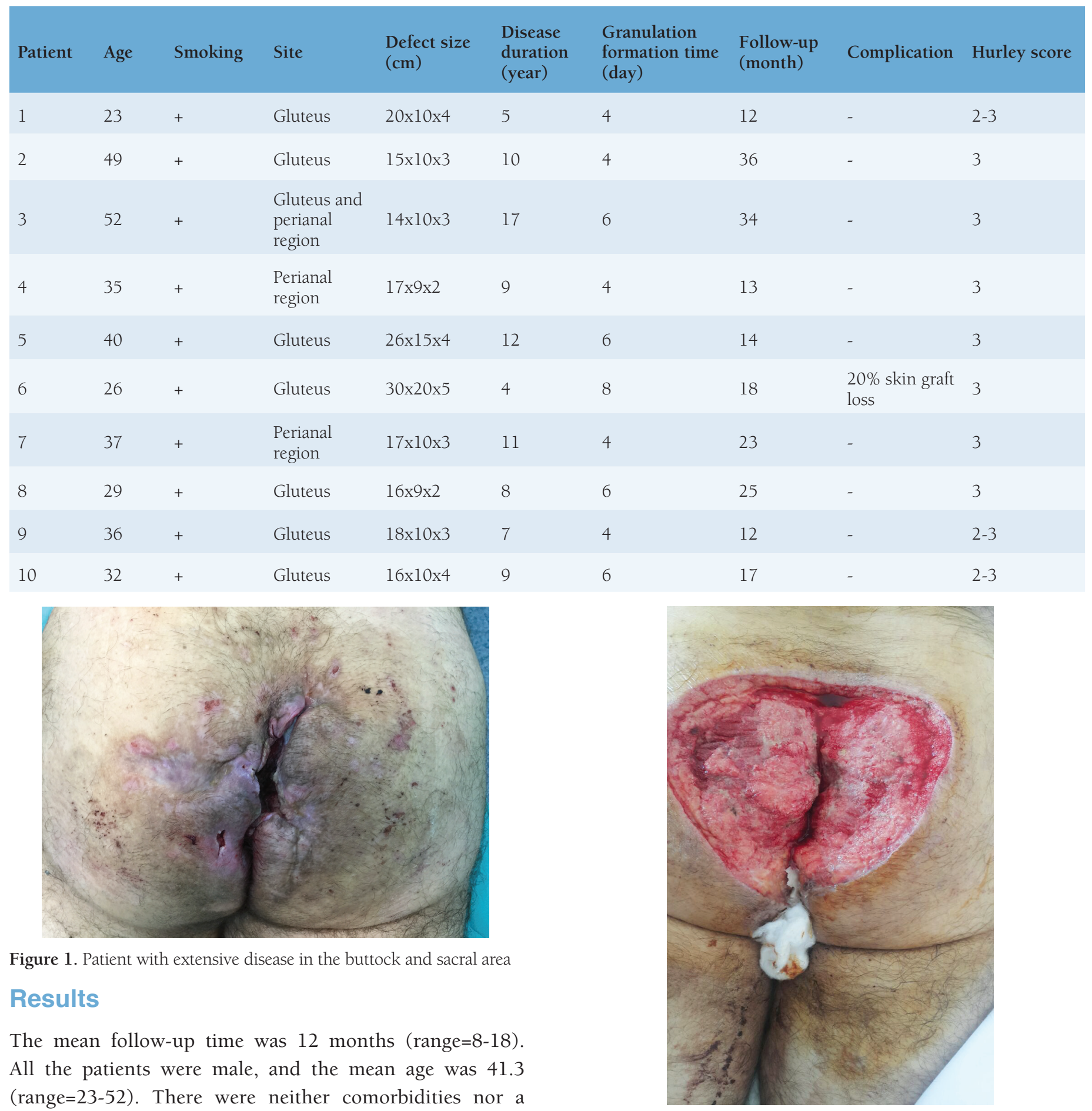
history of previous surgery present. The average time for the formation of granulation tissue was 5.4 days (range=4-8). Split thickness skin grafting was done after granulation tissue formation. NPWTi was applied for graft stabilization and sharing forces elimination. Grafts were kept under NPWT with instillation for five more days, and then standard wound dressing was carried out for three days. At the end of the eighth day, patients were discharged. The

Figure 2. Defect of wide local excision

mean hospitalization time was 14.3 (range=12-16) days (Figure 2).

There was no graft loss in nine patients. One patient lost $20 \%$ of his graft. Secondary healing was achieved with local wound care for this patient. There was no recurrence after a mean follow up time of 23.4 (12-36) months. Neither 
contour irregularity nor contracture was observed due to the graft loss.

\section{Discussion}

Patients with HS are generally sufferers of their disease for many years before surgery. ${ }^{7}$ The purpose of the treatment is to control the disease at an acceptable cosmetic level for a comfortable life and prevent recurrences as much as possible. ${ }^{5}$ Antibiotics, hormone replacement therapies, retinoids, and chemotherapy were shown to be effective in the management of HS. ${ }^{3}$ However, a complete cure can only be achieved with surgical excision and reconstruction. ${ }^{15}$ If left untreated, HS spreads to larger areas and mandates more extensive excisions. Most authors conclude that recurrence can only be avoided if complete excision with at least a $2 \mathrm{~cm}$ healthy tissue margin is performed, including adequate subcutaneous

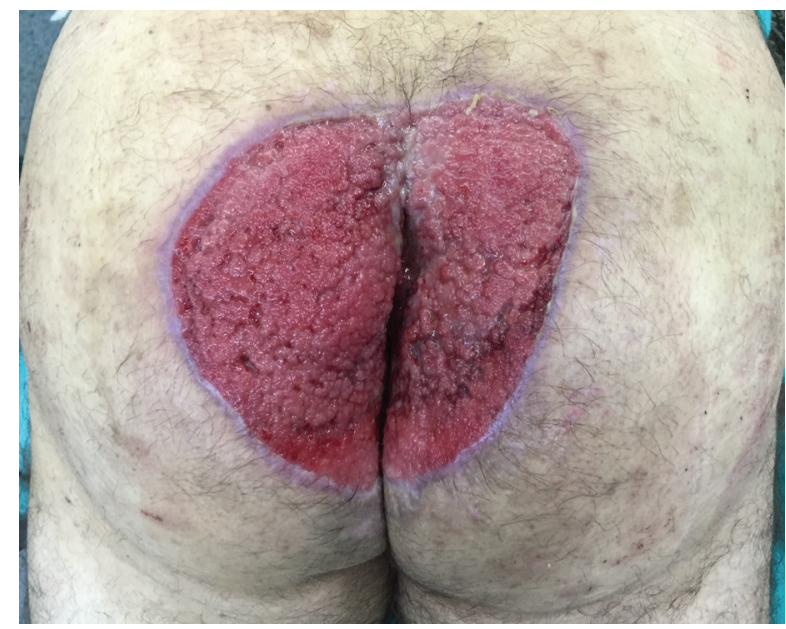

Figure 3. After negative pressure wound therapy with instillation treatment

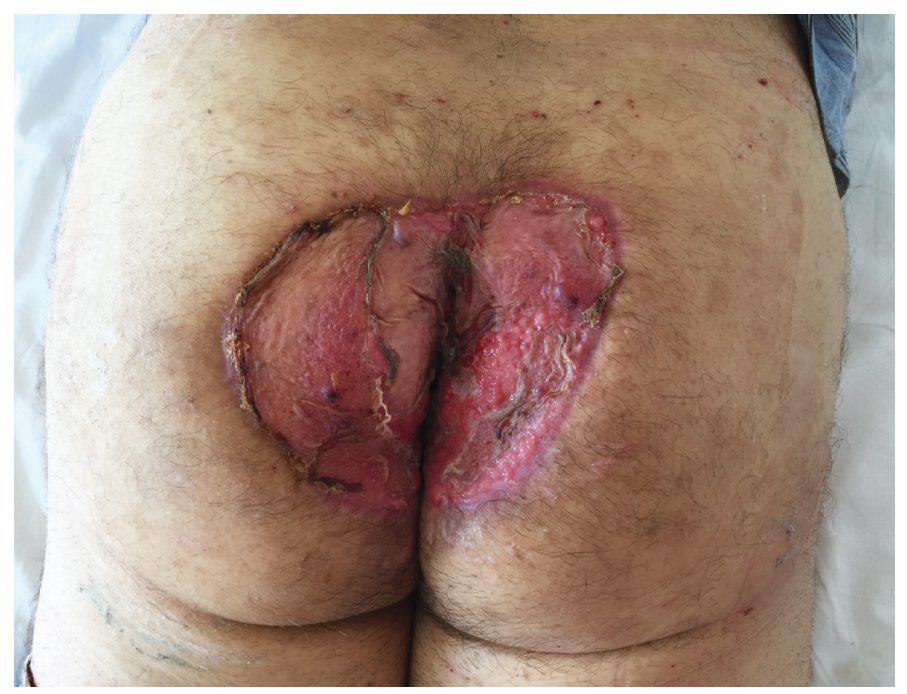

Figure 4. Autologous skin was grafted onto the wound base after negative pressure wound therapy with instillation treatment fatty tissue (not less than $5 \mathrm{~mm}$ ) or deep fascia., ${ }^{2,3,4,5}$ The complete excision of HS may result in a wide defect that does not allow primary closure. Secondary healing, skin grafting with or without NPWT, local or perforator flap treatments were proposed in the literature. . $^{2,3,4,5,6,7,8,9}$ Secondary healing after excision will take a long time that will reduce the patient's quality of life. Even though reconstructions with local flaps are considered to be an ideal approach for the prevention of contour irregularities, however, they have some disadvantages; recurrence may be the expected result since local flaps are prepared from the skin of the same anatomic region that has HS development tendency. ${ }^{7}$ Reconstruction considerations may also force surgeon for limited excisions that can cause unintentional leaving of the infected pilosebaceous gland and early recurrences. ${ }^{4}$ Wider local flaps also create perfusion problems. Reconstructions with the use of perforator flaps nowadays have become more popular for the solution of perfusion and size limitations of the conventional flaps. Perforator flaps can more easily be adapted to defect sites with advancement or propeller type rotations. Vascular structure and physiology of the perforator flaps make them suitable for thinning. Better contouring can be achieved. However, dissection of the perforator flap requires experience at a certain level and results in longer operation time. ${ }^{9}$ Closure of the wide defects with skin grafts is simple and quick. Chen et al. ${ }^{3}$ have used NPWT to increase granulation tissue formation and accelerate graft fastening. If excision is carried out until the muscular layer, contour deformity will almost be inevitable after the closure of the created defect with a skin graft. Fatty tissue with poor perfusion will come in front after the excision of HS, and skin graft survival will be reduced. ${ }^{6}$ The first two effects of NPWT treatment are the removal of tissue edema and augmentation of blood perfusion over the wound bed. ${ }^{16}$ Negative pressure destroys the integrin bridges in the cellular skeleton and triggers intracellular

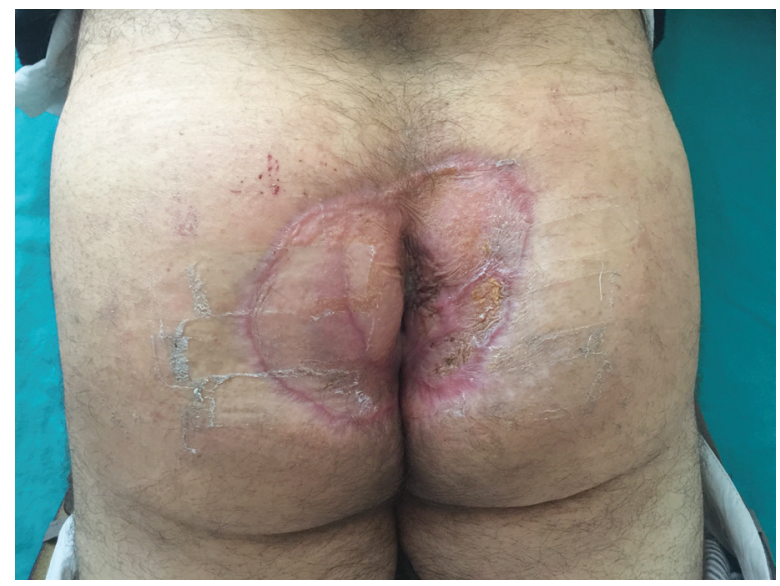

Figure 5. Post-op six month 
messaging, which in turn increases the proliferation and granulation tissue formation. Early formation of granulation tissue and inhibition of edema development that impairs microcirculation and oxygenation improve graft survival rate. ${ }^{17,18}$ NPWT application after grafting reduces the hematoma formation and graft lysis risks. It is also hard to immobilize the skin graft at the perianal and gluteal region. ${ }^{6}$ Skin graft loss will be higher unless meticulous wound dressing is carried out. NPWT treatment permits movement liberation, and this enhances patient tolerance and comfort. ${ }^{6}$ All devices used were portable. Even early mobilization of the patients was enabled; graft loss and health personnel workloads were reduced at the same time. The most frequent complication encountered after HS surgeries, including graftflap reconstructions and secondary healing, is infectious events. Wound dehiscence and graft lysis events happen more frequent after infection that prolongs the recovery and hospitalization periods. ${ }^{7}$ The bacterial load per gram wound tissue is reduced from $10^{7}$ to $10^{2}$ after the $4^{\text {th }}$ or fifth days of NPWT therapy. ${ }^{16}$ This data explains the absence of infection and low hospitalization periods that was 14.3 days in our study. Health care expenditure is reduced by reduction either in the hospitalization time preoperatively or post grafting intervention concerning conventional methods. Vuerstaek et al. ${ }^{19}$ have shown in their study dealing with chronic leg ulcer disease that preparation of wound bed to the surgery with the use of NPWT therapy is seven days while it takes 17 days with conventional procedures and demonstrated the beneficial effect of NPWT therapy with significant reduction in cost, pain and healing time. The use of NPWT systems before and after grafting for tissue defects has developed rapidly in recent years. ${ }^{16}$ The place of NPWT for the preparation of wound bed and granulation tissue formation is now unquestionable. On the other hand, NPWT may be insufficient for the wounds that are infected or require humidity balance establishment. ${ }^{19}$ In order to solve this problem, a continuous irrigation apparatus was added to the NPWT system that offers the desired humidity condition. In this way, continuous debridement and pus removal can be possible at the same time. Continuous irrigation reduces debris and bacterial load in extremely dirty wounds and accelerates granulation tissue formation by providing desired humidity balance. The choice of solution to be used for irrigation is still subject to discussion. A variety of solutions from saline to fluids containing antibiotics were tried out, but none of them has shown to be superior. ${ }^{20}$ NPWT techniques for perianal or gluteal regions give an advantage to the surgeons to improve patients' mobilization after reconstructions in these regions. ${ }^{6}$ We used NPWTi to facilitate patient follow up, mobilization, and quicken to pass definitive surgery. While granulation tissue formation time after conventional NPWT techniques and skin grafting was seven days, it was found to be five days in our study. The other purpose of using NPWTi after grafting procedure was the removal of the hematoma at the wound recipient site. Infection due to coagulum and debris materials was tried to be prevented. The graft survival rate was improved with this application. One another problem for chronically ill patients is long hospitalization times. NPWTi application reduced hospitalization time compared to the NPWT system. Preparation of wound bed and NPWT application over the skin graft help protection of wound infection. Besides the reduction of quality of life of the patients with psychosocial problems, despite rarely seen, the development of squamous cell carcinoma is the most dangerous complication of HS. ${ }^{21}$ That is why treatment and long term follow up is important for HS patients.

\section{Concluison}

In conclusion, HS is a chronic illness that has malignancy development potential if left untreated for a long time and creates personal hygiene and social problems. Surgical treatment is crucial for successful results. We demonstrate the time interval for the patients to be ready for excision and recovery time after grafting were significantly reduced. We concluded that NPWTi and grafting after excision for treatment of HS is beneficial when complication rate, cost, and allied achievement of health personnel workload reduction are considered.

\section{Ethics}

Ethics Committee Approval: Retrospective study.

Informed Consent: Retrospective study.

Peer-review: Externally peer-reviewed.

\section{Authorship Contributions}

Surgical and Medical Practices: E.S., A.D.U., Concept: A.A., Design: E.S., Data Collection or Processing: A.A., Analysis or Interpretation: A.D.U., Literature Search: E.S., Writing: E.S., A.D.U.

Conflict of Interest: No conflict of interest was declared by the authors.

Financial Disclosure: The authors declared that this study received no financial support.

\section{References}

1. Jemec GB. The symptomatology of hidradenitis suppurativa in women. Br J Dermatol 1988;119:345-350.

2. Menderes A, Sunay O, Vayvada H, Yilmaz M. Surgical management of hidradenitissuppurativa. Int J Med Sci 2010;7:240-247.

3. Chen YE, Gerstle T, Verma K, Treiser MD, Kimball AB, Orgill DP. Management of hidradenitis suppurativa wounds with an internal vacuumassisted closure device. Plast Reconstr Surg 2014;133:370e-377. 
4. Egemen O, Özkaya Ö, Orman Ç, Kayadibi T, Akan M. Our approach to patients with hidradenitis suppurativa and evaluation of outcomes. Turk Plast Surg 2013;21;11-16.

5. Hurley HJ. Axillary hyperhidrosis, apocrine bromhidrosis, hidradenitis suppurativa and familial benign pemphigus. Surgical approach. In Roenigk RK editor. Dermatologicsurgery Principles and Practice, 1st Edition. Newyork: MarcelDekker Inc.; 1996 p:623-45

6. Chen E, Friedman HI. Management of regional hidradenitis suppurativa withvacuum-assisted closure and split thickness skin grafts. Ann Plast Surg 2011;67:397-401

7. Balik E, Eren T, Bulut T, Büyükuncu Y, Bugra D, Yamaner S. Surgical approach to extensive hidradenitis suppurativa in the perineal/perianal and gluteal regions. World J Surg 2009;33:481-487.

8. Madan V, Hindle E, Hussain W, August PJ. Outcomes of treatment of nine casesof recalcitrant severe hidradenitis suppurativa with carbon dioxide laser. Br J Dermatol 2008;159:1309-1314.

9. Egemen O, Özkaya Ö, Bingöl D, Orman Ç, Akan M. Islanded perforator flaps inthe reconstruction of hidradenitis suppurativa defects. J Reconstr Microsurg 2013;29:297-302.

10. Damiani G, Pinnarelli L, Sommella L, Tocco MP, Marvulli M, Magrini P, et al. Vacuum-assisted closure therapy for patients with infected sternal wounds: a meta-analysis of current evidence. J Plast Reconstr Aesthet Surg 2011;64:1119-1123.

11. Kanakaris NK, Thanasas C, Keramaris N, Kontakis G, Granick MS, Giannoudis PV. The efficacy of negative pressure wound therapy in the management of lowern extremity trauma: review of clinical evidence. Injury 2007;38 Suppl 5:S9-18.

12. Gabriel A, Shores J, Bernstein B, de Leon J, Kamepalli R, WolvosT, et al. A clinical review of infected wound treatment with Vacuum Assisted Closure (V.A.C.) therapy: experience and case series. Int Wound J 2009;6 Suppl $2: 1-25$.
13. Roberts DJ, Zygun DA, Grendar J, Ball CG, Robertson HL, Ouellet JF, et al. Negative-pressure wound therapy for critically ill adults with open abdominal wounds: a systematic review. J Trauma Acute Care Surg 2012;73:629-639.

14. Scherer LA, Shiver S, Chang M, Meredith JW, Owings JT. The vacuum assistedclosure device: a method of securing skin grafts and improving graft survival. Arch Surg 2002;137:930-933; discussion 933-934

15. Ather S, Chan DS, Leaper DJ, Harding KG. Surgical treatment of hidradenitis suppurativa: case series and review of the literature. Int Wound J 2006;3:159-169.

16. Saxena V, Hwang CW, Huang S, Eichbaum Q, Ingber D, Orgill DP. Vacuumassisted closure: microdeformations of wounds and cell proliferation. Plast Reconstr Surg 2004;114:1086-1098.

17. Venturi ML, Attinger CE, Mesbahi AN, Hess CL, Graw KS. Mechanisms and clinical applications of the vacuum-assisted closure (VAC) device: a review. Am J ClinDermatol 2005;6:185-194.

18. Argenta LC, Morykwas MJ. Vacuum-assisted closure: a new method for wound control and treatment: clinical experience. Ann PlastSurg 1997;38:563-577.

19. Vuerstaek JD, Vainas T, Wuite J, Nelemans P, Neumann MH, Veraart JC. State of the art treatment of chronic leg ulcers: A randomized controlled trial comparing vacu- um-assisted closure (V.A.C.) with modern wound dress- ings. J Vasc Surg 2006;44:1029-1038.

20. Raad W, Lantis JC, Tyrie L, Gendics C, Todd G. Vacuum-assisted closure instill as a method of sterilizing massive venous stasis wounds prior to split thickness skin graft placement. Int Wound J 2010;7:81-85.

21. Ben AJ, Bouasker I, Najah H, Zribi H, Bedoui R, Guesmi F, et al. Squamous cell carcinoma arising in Verneuil's disease. Tunis Med 2008;86:169-170. 